\title{
CHILD ABANDONMENT: THE BOTCHED BEGINNING OF THE ADOPTION PROCESS
}

ADoptron aims to provide children with the security of parents and home. ${ }^{1}$ Statutes are intended to promote the best interests of the child while safeguarding the rights of natural and adoptive parents. ${ }^{2}$ Accordingly, the consent of the natural parents is generally a prerequisite to an adoption. ${ }^{3}$ If a child is adjudged abandoned, however, such consent is unnecessary. ${ }^{4}$ Abandonment

1. See Hall, The Law of Anoptron 5 (1928). The Children's Charter, drafted by the White House Conference of 1930, and often reaffirmed, provides: "For every child a home and that love and security which a home provides; and for that child who must receive foster care, the nearest substitute for his own home." STANDARds For CHILD Welfare Agenctes Placting Children in Foster Homies 9 (State Department of Public Welfare of Wisconsin 1948).

Adoption in the United States is authorized by statute in every state. For collection of statutes see 4 VERnIER, AMrerican FamiLy LAws, Tables CXXII-CXXV (1936).

On the history of adoption generally, see Brooks \& Brooks, Adventuring IN Adoption 93-110 (1939); PeCK, Adoption Laws in the United States 1-2 (Children's Bureau Publication No. 148, 1925).

2. See, e.g., the model Maryland statute. Its stated purpose is "[t]he three-fold protection of (1) the adoptive child, from unnecessary separation from his natural parents and from adoption by persons unfit to have such responsibility; (2) the natural parents, from hurried and abrupt decisions to give up the child; and (3) the adopting parents, by providing them information about the child and his background, and protecting them from subsequent disturbance of their relationships with the child by natural parents." MD. REv. Stat. Art. 16, §85(A) (1947). For an analysis of the content of a sound statute, see Essentials of Adoption Law and Procedure (U. S. Children's Bureau Publication No. 331, 1949).

3. See, e.g., Blue v. Boisvert, 57 A.2d 498, 501 (Me. 1948); In re Adoption of Southard, 358 Pa. 386, 393, 57 A.2d 904, 907 (1948).

4. See, c.g., In re Klines Adoption, 24 Del. Ch. 427, 429, 8 A.2d 505, 506 (1939); Young v. Smith, 231 S.W.2d 365, 369 (Tenn. 1950).

Many statutes specifically mention abandonment as an exception to the requirement for parental consent. E.g., MD. REv. Stat. Art. 16, \$85(G) (1947). For other exceptions to consent such as drunkenness, loss of civil rights, drug addiction, and deprivation of parental rights in a previous action, see 4 Vernier, AMERICAN FaMiLy Laws 340 ff. (1936). In jurisdictions where it is not specifically mentioned in the statute, abandonment is found in the judicial interpretation of the statute. See, e.g., Shumway v. Farley, 68 Ariz. 159, 162, 203 F.2d 507, 509 (1949) (statute makes desertion an exception to consent; court states that desertion is synonomous with abandonment and uses abandonment definitions and citations); Nugent v. Powell, 4 Wyo. 173, 189; 33 Pac. 23, 26 (1893) (statute says parent must consent; court holds that one who abandons a child is no longer a "parent" within meaning of statute). Abandonment may be the basis of court action in a hearing prior to the adoption proceeding, or decided in a juvenile court proceeding under Dependent, Neglected, and Delinquent Children's acts. E.g., IND. Stat. Ann. 9-3206 (Burns 1946).

Provisions for abandonment in adoption statutes are frequently coupled with prerequisite time periods. E.g., Alaska Comp. Laws ANs. \$21-3-13 (1949) (abandonment for a period of not less than thirty days preceding the filing of the petition [of adoption]); 
is conduct of the natural parent which renounces the parental relationship. ${ }^{5}$ When this occurs, persons who wish to adopt, or a child placement agency, may initiate an action against the natural parent to terminate parental rights. ${ }^{6}$

Neb. Rev. Stat. 43-104 (1943) (6 months); South Dakota Code 14.0403 (1939) (1 year); Vernon's Annotated Texas CIVIL Statutes art. 46(a), 6 (cum. supp. 1950) (2 years).

Difficulty and delay are incurred through the use of abandonment provisions of adoption statutes which are frequently coupled with extended time prescriptions. Hence agencies may prefer to use the "neglect" provisions of juvenile court acts, which have no time requirements for abandonment, to have custody awarded to a temporary guardian who will later consent to an adoption. See communication to the Yale LAw Journal from Mr. John A. Winters, Executive Director, Texas Department of Public Welfare, dated May 22, 1951, in Yale Law Library.

Many states require a trial period in the adoptive home before a final decree of adoption. See Comment, 59 Y ALE L.J. 715, 730 (1950). Some agencies allow the required time period for abandonment to run concurrently with the trial period between the temporary and permanent adoption decree. "[W] here both parents desert a child, we usually go to court and ask for custody on the basis of neglect. Then we may place the child for adoption and a year later, at the consummation, ask that parental rights be terminated on the basis of abandonment." . . . Communication to the YALE LAW Journal from Mr. Kenneth Dick, Administrative Assistant, St. Louis Family and Children's Service, dated May 17, 1951, in Yale Law Library. This policy of allowing the time to run concurrently creates a period of uncertainty which may bring undesirable results to either the natural or adoptive parents: (1) It may fail to give the natural parent adequate protection since the judge will be reluctant to remove a child from an adoptive home in which he has spent considerable time. See, e.g., Appeal of Hazuka, $345 \mathrm{~Pa} .432,435-6,29$ A.2d 88, 89 (1942). (2) A delay of final abandonment determination may fail to protect the adopting parents, by allowing the natural parents to reclaim the child from a desirable adoptive home. See, e.g., In re Anonymous, 85 N.Y.S.2d 358 (Westchester County Surr. Ct. 1948).

5. Winans v. Luppie, 47 N.J. Eq. 302, 305, 20 Atl. 969 (1890) (leading definition of abandonment as "settled intent to renounce the parental relationship"). Many kinds of conduct have been held to constitute abandonment. See note 8 infra.

6. See, e.g., In re Anonymous, 80 N.Y.S.2d 839 (Westchester County Surr. Ct. 1947) ; In re Davies' Adoption, 353 Pa. 579, 46 A.2d 252 (1946) ; Hammond v. Eplen, 216 S.W.2d 258 (Tex. Civ. App. 1948).

A termination of parental rights may be sought when the natural parent refuses consent to adoption, withdraws consent already given, or is unavailable. Smith v. Crivello, 338 I1l. App. 503, 88 N.E.2d 107 (1949) (abandonment action against natural parent who withheld consent) ; Wright v. Fitzgibbons, 198 Miss. 471, 21 So.2d 709 (1949) (abandonment action against natural parent when consent withdrawn); Lucas v. Strauser, 65 Wyo. 98, 196 P.2d 862 (1948) (abandonment found when father unavailable, but he returns in time to reverse finding). Agency heads suggest that the largest group of cases using abandonment are (1) actions in which legitimate children are adopted by relatives or stepfathers, and (2) those where the local public welfare department or child placement agency must pay support if the child is not adopted. These may be cases in which (a) the children were originally placed temporarily by their parents or relatives without intending adoption, but were left so long in the care of temporary foster parents that the latter refused to allow them to return to their parents, (b) the parents have disappeared, or (c) the parents leave without carrying out a court order to assist in support of the child. Communication to the Yale Law Journal from Mr. Fred Delli Quadri, Wisconsin Department of Public Welfare, dated May 21, 1951, in Yale Law Library; communication 
Usually this is done as part of an adoption proceeding.?

But old abandonment doctrines often frustrate the desirable objectives of adoption statutes. Abandonment must be willful; regardless of the parents' actual treatment of the child, a "settled intent" to renounce permanently the rights and duties of parenthood must be established. ${ }^{8} \mathrm{~A}$ heavy burden of proof rests upon those seeking to establish an abandonment, and the court

to the Yale Law Journal from A. A. Fredricks, Director, Louisiana Department of Public Welfare, dated May 8, 1951, in Yale Law Library.

Attorneys consider these cases among the most difficult in the adoption field. Pilling, The Co-operation of the Case Worker and the Legal Aid Attorney in Adoption, 2 Socral Work TeCHNigUe 127, 131 (May-June 1937).

7. See, e.g., Smith v. Crivello, 338 Ill. App. 503, 88 N.E.2d 107 (1949); In re Anonymous, 195 Misc. 6, 88 N.Y.S.2d 829 (1949); communication to the YALE LAw Journal from Mrs. J. T. Roos, Supervisor of Licensing, Delaware State Board of Welfare, dated May 7, 1951, in Yale Law Library; communication to the YALE LAW Journal from Harold A. Hagen, Director, North Dakota Division of Child Welfare, dated May 16, 1951, in Yale Law Library.

8. See, e.g., In re Gates' Adoption, 84 Ohio App. 269, 85 N.E.2d 597 (1948) (although court finds failure to provide home, food, care, clothing, lack of allegation of "willful" conduct in petition allows parent to prevent adoption); In re Schwab's Adoption, $355 \mathrm{~Pa} .534,50$ A.2d 504 (1947) (unfit mother prevents adoption).

Settled intent and "willful" have long been synonomous criteria, Winans v. Luppie, 47 N.J. Eq. 302, 20 Atl. 969 (1890). Their content varies in different jurisdictions, however. See, e.g., People v. Bowdry, 324 Ill. App. 52, 57 N.E.2d 287 (1944) (time is not an element of abandonment except as "evidence" of intent) ; contra: In re Graham, 239 Mo. App. 1036, 199 S.W.2d 68 (1947) (full statutory time period is an absolute requirement).

Criteria may differ within the states also. Communication to the YAIE LAw Journal from Mrs. Edward Gresham, Director, Alabama Department of Public Welfare, dated May 8, 1951 in Yale Law Library. Communication, Texas Dept. of Welfare supra note 4 , in Yale Law Library.

Further definition difficulties are created by the various abandonment and consent problems of divorce. On the consent to adoption required when the natural parents are divorced, see Colby, Protection of Children in Adoption, 65 Proceedings of the National Conference "OF Social Work 146, 152 (1939); Note, 91 A.L.R. 1387 (1934). In the absence of statutory provisions abandonment is frequently used in lieu of the consent of the divorced parent not having custody of the child. However, if a parent is deprived of custody by a court, then absence and lack of support are no longer criteria of intent, and abandonment is extremely difficult to establish. Zalis v. Ksypka, 315 Mass. 479, 53 N.E.2d 104 (1944) (father divorced and deprived of custody cannot "willfully" abandon); McComas v. Glendinning, 188 Ga. 345, 3 S.E.2d 562 (1939) (since father deprived of custody his failure to support is not "willful" abandonment); contra: Shumway v. Farley, 68 Ariz. 159, 203 P.2d 507 (1949). When support is part of the divorce decree, failure to pay usually is abondonment. In re Kelly's Adoption, 47 Cal. App. 2d 577, 118 P.2d 479 (1941) (if father can but does not pay for support, mother alone can consent). Some statutes make consent unnecessary under certain grounds for divorce e.g., N.Y. DoMr. REL. L. $\S 111$ (1948) (adultery). Other jurisdicitions require consent even when the divorced parent has no visitation privileges and no support requirement. V-568, Opinions of Atty. General of Texas (1948). 
resolves all doubts in the natural parents' favor. ${ }^{9}$ In addition, abandonment is a "continuing process." Even though their previous conduct showed an intent to abandon, natural parents may change their minds and reclaim their child from a foster home on the eve of adoption. ${ }^{10}$ Termination of parental rights thus is difficult and uncertain $;^{11}$ years later parental claims may crop

9. The burden of proof combines with strict construction of statutory requirements to make abandonment difficult to establish. Courts state that all exceptions to consent must be construed strictly to protect parental rights, for adoption is created by statute and not common law. See, e.g., People $e x$ rel. Cucuzza v. Cobb, 196 Misc. 961, 963, 94 N.Y.S.2d 616, 618 (Sup. Ct. Bronx County 1950) (abandonment fails to meet burden of proof).

10. See, e.g., In re Graham, 239 Mo. App. 1036, 1046, 199 S.W.2d 68, 74 (1947) (abandonment is a continuous thing: parents prevent adoption of child after more than a year of abandonment).

Frequently the problem of parents making belated claims for their children arises when the parents give voluntary consent to adoption in some form, perhaps a release at childbirth, abandon the child, and then attempt to withdraw consent and oppose an abandonment action. Whether a natural parent who has given his consent may revoke it before a final decree of adoption has been entered is unsettled. See Notes, 32 MINN. L.R. 496 (1948) ; 26 N.C.L. Rev. 293 (1948) ; Annotations : 156 A.L.R. 1011 (1945); 138 id. 1038 (1942).

To the parent a written release of any kind seems final. Yet the fact that a parent signs a "consent to adoption" does not as a rule terminate the parental relationship or bestow upon another person rights which can be obtained only through actual legal guardianship or adoption proceedings. Morlock, Relinquishment and Adoption, 25 CHILD WELFARE 3 (Nov. 1946).

The courts have taken several stands on the problem of revocation of a release when coupled with abandonment:

(1) The majority view is that such a release is not binding since it fails to identify the adopting parent and is not part of the adoption proceeding. In re Holder, 218 N.C. 136, 141, 10 S.E.2d 620, 622 (1940). Under this approach the parents have an absolute power to revoke at any time before final judgment "even though the natural parent had abandoned the child." Paschke v. Smith, 214 S.W.2d 205, 207 (Tex. Civ. App. 1948).

(2) Courts have held that abandonment may be by legal instrument as well as conduct, indicating that perhaps written releases alone may satisfy the "intent" criteria. Appeal of Hazuka, $345 \mathrm{~Pa}, 432,435,29$ A.2d 88, 89 (1942). But ustually the strongest position taken against the natural parents is that a written release is "evidence" of intent to abandon. E.g., Commonwealth v. Edburg, $346 \mathrm{~Pa}$. 512, 515, 31 A.2d 84, 85 (1943).

(3) A compromise solution introduces the interests of the child once any abandonment is found. Although the child's welfare is not considered in determining whether abandonment has existed, as soon as it has been found a parent may revoke a written release only at the court's discretion after the child's interests are considered. Kalika v. Monro, 323 Mass. 542, 83 N.E.2d 172 (1948) ; In re Diana, 165 Pa. Super. 12, 67 A.2d 751 (1949). Here, although abandonment may not have been "continuous" enough to provide a full exception to parental consent, the fact that it existed at all forces closer scrutiny by the court of the otherwise absolute power of the natural parent to revoke consent.

For an analysis of formal statutory relinquishment see Comment, 59 YALE L.J. 715, 726-9 (1950).

11. In addition to the legal obstacles judges, lawyers, and social workers may be reluctant personally to terminate parental rights. "Judges sometimes become rather sentimental about abandonment proceedings. They don't want to be the ones who 'took the child from its mother." Communication to the YALE LAw Journal from Miss Lydia 
up to plague both child and adoptive parents. ${ }^{12}$ Desirable adoption placements are prevented. ${ }^{13}$ Adoption decrees are invalidated, or subject to constant threat of attack. ${ }^{14}$ Even when a court puts a child in the custody of a children's agency, it is uncertain whether the parents, the agency, or both must consent to an adoption. ${ }^{15}$ Sometimes a court may, for the child's sake, award

Schreiner, Secretary, Waverly Baby Home, Portland, Oregon, dated May 29, 1951, in Yale Law Library. See also communication to the YaLE LAW Journal from Proctor N. Carter, Director, Missouri Division of Welfare, dated May 2, 1951, in Yale Law Library.

12. See, e.g., Crawford v. Arends, 351 Mo. 1100, 176 S.W.2d 1 (1943) (defect in adoption decree based on abandonment appears seventeen years later); People ex rel Cocuzza v. Cobb, 196 Misc. 961, 94 N.Y.S.2d 616 (Sup. Ct. Bronx County 1950) (natural parents reclaim six-year-old child which had been in adoptive home from birth); In re Schwab's Adoption, 355 Pa. 534, 50 A.2d 504 (1947) (adoption prevented after several years of "neglect").

Most of these cases could be cured by a short statute of limitations. A recent North Dakota Statute has a unique approach, NoRTH DAkora Rev. CoDE tit. 14 \$1116 (1943 as amended, 1949). The Act provides for an automatic legal abandonment, terminating all claims of natural parents, after a child has been in an adoptive home for two years. The statute differs from other statutes of limitations in that there is a "conclusive presumption" that the natural parents have abandoned the child and consented to the adoption whether or not the adoption decree is valid.

13. See, e.g., In re Paden, 43 N.Y.S.2d 305 (King's County Surr. Ct., 1943), (illegitimate child in adoptive home over three years; court, refusing to sever "blood ties" holds no abandonment); McComas v. Glendinning, 188 Ga. 345, 3 S.E.2d 562 (1939) (divorced father who has not supported or seen the child since wife's remarriage prevents adoption).

14. See, c.g., In re Anonymous, 85 N.Y.S.2d 358 (Westchester County Surr. Ct. 1948) (mother who left child and signed release allowed to revoke during six-month trial period after interlocutory decree of adoption since no abandonment); Zalis v. Ksypka, 314 Mass. 479, 53 N.E.2d 104 (1944) (decree overthrown since abandonment by father only partially proved); In $r e$ Holder, 218 N.C. 136, 10 S.E.2d 620 (1940) (decree overthrown ten years later for failure to obtain consent or prove abandonment).

15. Child agencies and institutions frequently have children committed to their care, custody, and control; but the court order does not always indicate whether they have the right to consent to adoption. In every action where parents' rights are affected the order should state clearly whether all rights of the parents are terminated and what rights are transferred to the agency. Morlock, Relinquishment and Adoption, $25 \mathrm{C}_{\mathrm{BIID}}$ Welfare No. 9, 2 (Nov., 1946).

Confusion may result from: (1) failure on the part of the court to indicate clear agency authority, ibid; (2) subsequent change in condition, as when children are awarded to the custody of institutions and their parents disappear or neglect to pay for maintenance as required by court order, PECK, Adoption LAws IN THE U.S. 13-4 (Children's Bureau Publication No. 148, 1925); (3) failure of the state to make any provision for termination of parental rights in juvenile court actions, e.g., Missouri, communication, Missouri Division of Welfare, supra, note 11; (4) existence of relatives who may have a legal claim on the child, Wilson, What the Layman Does Not Know About Adoption, 26 ChILd Welfare, 14 (June, 1947); (5) legal conflicts between agencies and temporary homes in which the agency placed children for an extended period of time, Kelly, The Boarding Parents Apply to Adopt-A Dilemma, 26 Child Werfare, 1, 3 (Dec., 1947). 
custody to foster parents, yet natural parents who neglected their duties retain "legal title" and claims to the child's filial obligations. ${ }^{16}$ In short, abandonment proceedings subordinate the best interests of the child to the claims of parents and the dictates of inflexible doctrine. ${ }^{17}$

Abandonment doctrines should harmonize with general adoption legislation. ${ }^{18}$ Courts should emphasize parental duties as well as rights and view

If any irregularity exists in the agency's activity or authority it may turn up years later to produce unjust results. Ward v. Howard, 217 N.C. 201, 7 S.E.2d 625 (1940) (though child was placed in chidren's agency by court as "neglected," child robbed of inheritance years later because agency consented to adoption without authority).

16. See, e.g., In re Marks, 59 Misc. 348, 287 N.Y. Supp. 800 (Westchester County Surr. Ct. 1936) (father gave custody to aunt until child reached majority; held, no abandonment; father could not get child back, yet aunt couldn't adopt); "[W]e know of an instance in which a stepfather has supported his stepchild for many years and has wanted to adopt her; the father has opposed the adoption and has contributed a small amount of money toward the child's support just frequently enough to avoid the two-year abandonment clause from being used." Communication, Texas Department of Public Welfare, supra note 4.

In general the parents' rights are: custody, discipline, earnings, and property of the child. Parental duties are: support, education, and protection. In addition there are reciprocal rights of inheritance, and the child is subject to a duty to support parents and other relatives. For a complete analysis with relevant statutes, see 4 VERNIER, American Family Law 7 ff. (1936).

Custody is only one of the parent's rights. Hence, when a parent is deprived of custody this does not mean that all parental rights are terminated.

17. See People ex rel. Cocuzza v. Cobb, 196 Misc. 961, 962, 94 N.Y.S.2d 616, 617 (Sup. Ct. Bronx County 1950); Caruso v. Caruso, 175 Misc. 290, 292-3, 23 N.Y.S.2d 239, 242 (Sup. Ct. Bronx County 1940); Platt v. Moore, 183 S.W.2d 682, 685 (Tex. Civ. App. 1944).

"In Delaware in private adoptions, the question of abandonment is usually determined without consideration of the child's welfare". Communication, Delaware Board of Welfare, supra, note 7; "Consideration of the child's welfare does not (or should not under the law) enter into the question of abandonment." Communication to the Yale Law Journat from Mr. Wayne $\mathrm{H}$. Prather, Acting Director, Bureau of Children's Services, Pennsylvania Department of Welfare, dated May 3, 1951 in Yale Law Library; communication to the YaLe Law Journal from Mr. Miles R. Wyatt, Jr., Texas Cradle Society, dated May 15, 1951, in Yale Law Library; communication to YaLE LAw Journal from Mr. John Farr Larson, Director, Utah Department of Public Welfare, dated May 2, 1951, in Yale Law Library.

One court, unable to consider the child's welfare in an abandonment action and finding no abandonment, suggested that plaintiff try a habeas proceeding for the child's custody, in which welfare is considered. In re Daugherty's Estate, $358 \mathrm{~Pa} .620,62458 \mathrm{~A} .2 \mathrm{~d} 77$, 80 (1948)

It is suggested, however, that consideration of the child's welfare is implicit and cannot really be avoided. Communication, Louisiana Department of Public Welfare, supra, note 6.

18. "No law relating to the weilfare of children stands by itself. The principles and the standards essential for full protection of children must be the foundation of a whole 
abandonment as a violation of parental trust toward the child. ${ }^{19}$ Evidence of neglect, lack of support and desertion, introduced to show abandonment, would throw some burden of proof upon the natural parent. ${ }^{20}$ Although economic or emotional duress, for example, might furnish some justification

network of statutory and administrative provisions benefiting children. This interdependence is illustrated forcefully by the adoption law, which, although dealing with a specific area of protective legislation itself, depends upon many other legal provisions and administrative practices for its effectiveness as an instrument to safeguard children."

Essentials of Adoption Law and Procedure 7 (Children's Bureau Publication No. 331, 1949). See also, State of New York, Report of the Spectal Comsititee on Soctal Welfare and Relief of the Joint Legislative ComastTtee on Interstate Cooperation (Assemblyman Harold C. Ostertag, Chairman) 22 (Legislative Document No. 51, 1948) (hereinafter cited as Ostertag Report).

19. Such language has been used by the courts for half a century in relation to adoption.

"The right of the parents is not an absolute right of property, but is in the nature of a trust reposed in them, and is subject to their correlative duty to care for and protect the child; and the law secures their right only so long as they shall discharge their obligation." Purinton v. Jamrock, 195 Mass. 187, 201, 80 N.E. 802, 805 (1907). For a modern paraphrase applied to abandonment by divorced father, see Shumway v. Farley, 68 Ariz. 159, 163, 203 P.2d 507, 510 (1949).

In all jurisdictions there are criminal provisions concerning desertion, neglect and abandonment. 4 VerNIER, AMIERICAN FAMILY LAWS \$234 (1936) (compilation of the statutes). A typical statute provides, "... if any father or mother shall willfully abandon his or her child or children ... he or she shall be guilty of a misdemeanor: provided, that the abandonment of children by the father or mother shall constitute a continuing offense . . E Effective April 5, 1949." North Carolina Code $\$ 14-322$ (1949).

In a few states the only criteria utilized for child abandonment are those furnished by criminal abandonment statutes. Communication to the YALE LAw Journal from Mr. R. F. Spurk, Head of Legal Service, Minnesota Division of Public Welfare, dated May 7, 1951, in Yale Law Library; accord: communication to the YALE LAw JourNaL from Drury B. Thompson, Staff Attorney, North Carolina Department of Public Welfare, dated May 8, 1951 in Yale Law Library.

20. One method of shifting the burden of proof might be to relate performance of parental obligations to "presumptive evidence of intent." Some united attempts have been made along this line. See CAL. WeLf. \& InstrT. CoDE $\$ 701$ (a) for definition of abandoned child as one "who has been left by ... his parents in the care or custody of another without any provision for his support, or without communication from either or both of his parents, for the period of one year with the intent on the part of such parent or parents to abandon such person. Such failure to provide, or such failure to communicate for the period of one year, shall be presumptive evidence of the intent to abandon ..."

Where intent to abandon is truly a criterion it would seem dangerous to use such definite language and specific time prescriptions as in the California statute, however, for one letter with money enclosed might serve to remove the presumption. Pending legislation in Texas attempts to overcome this objection by changing its statutes to read "substantial provision" for the support of the child. Communication, Texas Department of Welfare, stipra note 4. But time proscriptions and "intent" seem contradictory. Time may be evidence of intent but should never be conclusive evidence against intent. 
for parental behavior, ${ }^{21}$ the principal basis of decision in an abandonment must be the child's welfare and happiness. ${ }^{22}$

Effective alignment of abandonment proceedings with the social aims of adoption, however, requires full utilization of both public and private child placement agencies. Their investigative facilities are presently best fitted to furnish the information upon which the court must largely base its determination. ${ }^{23}$ But agency reports, now chiefly concerned with the child's welfare and future parents' qualifications, are seldom used in abandonment proceedings because attention is centered on the natural parents. ${ }^{24}$ Since agency investigation of the adoptive home is a usual statutory prerequisite to adoption, ${ }^{25}$ the scope of the inquiry might well be broadened to include the natural parents and thus cover not only adoption but also abandonment. Investigation might help both parent and child, for agencies could furnish remedial aid and advice to the natural parents in addition to representing the interests of the child. On the other hand, courts must retain their judicial impartiality in an abandon-

21. Since the courts are concerned with the rights of natural parents, they are already doing their part in this area. Few cases where the natural parents are under duress have ruled against them, for this is directly contrary to the premise of "wilful" abandonment on their part. See e.g., In re Adoption of Susko, 363 Pa. 78, 69 A.2d 132 (1949).

The greatest area of difficulty is that of unmarried mothers who may make hasty decisions. A few remedial statutes now require a release by a court, and a waiting period before it is valid. See Comment, 59 YALE L.J. 715, 730-31 (1950). These statutory provisions, aside from the problem of their enforcement, are still inadequate to solve an emotional problem which demands the personal touch of agency case work. Hutchinson, Reexamination of Some Aspect of Case Work Practice in Adoption, 25 CHILd WeLfare 4 (Nov. 1946).

22. The "intent" theory of abandonment presently used, may be attacked as contradictory to the basic purpose of the child welfare statutes which make the interests of the child paramount. What importance to a child is it if his parents do not "intend" to rob him of the health and security of a happy home, if such a home is not provided?

23. Authorized adoption agencies are of three general types: state welfare departments, private agencies engaged solely in adoption work, and private agencies whose adoption activities are only one part of a general child welfare program. Comment, 59 YALE L.J. 715, 717 (1950).

"[A]gencies . . . are set up to render all the service needed within their field. The court . . . must depend entirely on other agencies to provide the prescribed services. No juvenile court can be better than the agencies which furnish the cases, facts, and information upon which it bases its judgment or to which it entrusts the execution of its orders." Wylegala, Children's Courts, an Effective Aid to Social Agencies, 28 CHID WeLFARE 7-8 (July 1949). See also Breckenridge, The Family and the State 364 (1934).

24. Some jurisdictions do not even authorize agency investigation until after abandonment has been determined.

"The question of abandonment and adoption is usually considered in the same judicial proceeding in Delaware in the case of private adoption as against adoption placements. The questions are kept separate in the sense that abandonment is determined before an Order of Reference ordering a social study is signed by the Orphan's Court." Communication, Delaware State Board of Welfare, supra note 7.

25. Idaho, Mississippi, Oklahoma, South Carolina, and Wyoming are the only states which make no provisions for social investigation of any sort. For a recent survey of statutes, see Comment 59 YALE L.J. 715, 729 n.76 (1950). 
ment proceeding. Agency reports deserve the weight accorded expert testimony, but should not be conclusive. ${ }^{26}$ The plight of the child must not be over-emphasized. Nor should a parternalistic judge who fancies himself a child expert be allowed to brush aside parental rights without a full hearing. ${ }^{27}$

Ideally, agencies should act as an insulating intermediary between natural and adoptive parents. If the parties and the proceedings in abandonment and adoption were kept separate, termination of parental rights would not be mixed with problems of placing the child with adopting parents. ${ }^{28}$ With separation, judicial evaluation of new and old parents will no longer be biased by comparing them. ${ }^{29}$ A better home may not be a good home. Moreover, separation of the parties ensures secrecy necessary to prevent anxiety and strife. Natural parents will not threaten or interfere with the child's new home. ${ }^{30}$ Separate

26. See Wylegala, supra note 23 , at 8 .

27. In adoption notice must be given to the natural parents in almost all cases. See Annotations, 24 A.L.R. 416 (1923) 76 id. 1077 (1932). Statutes also require notice. See collection of statutes in all states 4 Vernier, American FaMilu Law \& 252 (1936).

Where abandonment is a substitute for parental consent and terminates parental rights, parents should have their day in court in the abandonment proceeding. Love, How Adoption Proceedings Should Be Handed 8 (Speech at Annual Meeting Oklahoma Bar Association Nov. 1949) (Hereinafter cited as Love, OkzA. SpEecr). The cases vary: Estate of Hampton, 55 Cal. App.2d 543, 131 P.2d 565 (1942) (since no notice, no abandonment and no adoption, decree overthrown years later); Finn v. Rees, 65 Idaho 181, 141 P.2d 976 (1943) (abandonment upheld although no notice to father); Hill v. Patton, 43 N.M. 21, 85 P.2d 75 (1938) (parent always entitled to hearing if abandonment found without notice, but adoption decree stands unless father proves no abandonment when he gets hearing); In re Asterbloom's Adoption, 63 Nev. 190, 165 P.2d 157 (1946) (five-year abandonment estops father from attacking adoption on grounds of lack of notice).

For the limits of a court's function and the danger of the "child-expert" judge who is fortified with theory, see Keith-Lucas, Social Work and the Court in the Protection of Children, 28 ChIID Welfare 4, 5 (July 1949).

Some courts may appoint a "next friend" on the spot to give the required consent without investigation. He may not even know the child. Essentrals of Adoptron Law and Procedure 15 (Children's Bureau Publication No. 331, 1949); Colby, Problemss and Procedures in Adoptron 94-5 (Children's Bureau Publication No. 262, 1941) ; Milllinix, Ohio Adoption Study 62 (mimeographed 1940).

28. Many social workers believe that abandonment should be kept separate from adoption. See, e.g., the opinion of the U.S. Children's Bureau, the nation's leader in this work: "We believe that termination of parental rights for abandonment, as well as for other reasons, and the granting of the adoption decree should be separate proceedings." Communication to the YALE LAw JouRNaL from Marguerite Windhauser, Legislative Consultant, Federal Security Agency, Children's Bureau, dated June 6, 1951, in Yale Law Library.

29. It is difficult to avoid comparisons when adoption and abandonment are part of the same proceeding, and it is perhaps inevitable that the determination of each issue on its merits will be affected. See Note, U. of CHI. L. Rev. 303, 307 n. 16 (1947); Colby, Protection of Children in Adoption, 65 Proceddings of the National Conference or SOCTAL WORKERS 146, 153 (1939).

30. Agencies must act as a "buffer" to prevent harrassment and even blackmail. Love, Okta. Spezcr 11 et. seq. For discussion of the desirability of stuch insulation and 
abandonment proceedings to which the agency is a party should fulfill all notice requirements and avoid undesirable publicity at adoption. ${ }^{31}$ Effective separation of parties and proceedings, however, must await further expansion of agency facilities. Present inadequacies are largely responsible for the high percentage of adoptions arranged without agency aid. ${ }^{32}$ In such cases the question of abandonment often does not arise until the petition for adoption, when the child has already spent some time in the future adoptive home: ${ }^{33}$ Abandonment may then become a fight between two sets of parents with adoption pending the result. Agencies are needed to represent the interests of the child.

Although probate and district courts now have jurisdiction over the bulk of abandonment proceedings, "social courts" are better suited for these actions. $^{34}$ Juvenile or children's courts have accumulated helpful experience

the use of "confidential records" See Essentials of Adoption Law and Procedure 4, 24 (Children's Bureau Publication No. 331, 1949); Report of the OKLAHOMa ChILdren's Code Courarssion 30 (mimeographed 1948).

In the absence of agency "insulation" adoptive parents frequently seek their own solution in flight to a new home unknown to the natural parents. Seeley, Adoptions: Maryland's Better Way, 37 SuRveY GRAPHIC 255 (May 1948).

31. The U.S. Children's Bureau feels that provisions for notice to natural parents should be removed altogether from present adoption legislation. Either the parents consent to the adoption or their rights are terminated at a separate proceeding prior to adoption in which notice to the natural parents is required. EssEnTIAIs IN ADOpTION LAW and Procedure 16 (Children's Bureau Publication No. 331, 1949).

32. For an excellent recent analysis of agency deficiencies see Comment, 59 YALE L.J. 715 (1950). Examples of states where many adoptions are arranged without agencies are: Maine, where private placements in 1948 were ninety-one per cent of the total, $i d$. at 733 and Florida, where in 1948 eighty per cent were privately placed. WARd, ANALIXsis of Adoptions 1943-1949 (Florida State Welfare Board 1949). A survey of fifteen states in 1944 indicated that only approximately one-quarter of the placements were handled by an authorized agency. Zarefsky, Children Acquire New Parents, 10 Cнпnd 142, 143 (1946).

33. "[W] here the child has been placed for adoption directly by the mother, or perhaps by some unauthorized intermediary ... no preliminary steps are usually taken to establish abandonment or to terminate the parental rights in any form prior to the adoption hearing itself. These are what we generally call the 'independent placements', and as a rule, no effort is made to keep the identity of the different parties concealed from each other." Communication, North Dakota Board of Welfare, supra note 7.

On the difficulties of removing a child from a foster home, see Mullinnix, OHIo Adoption Study 79 (mimeographed 1941); Ostertag Report 25; Colby, Protection of Children in Adoption, 65 Proceedings of the National Conference of Soctal Work 146, 154 (1939).

34. Unfortunately juvenile courts do not have jurisdiction over adoption proceedings, although they may obtain jurisdiction in cases where the child is under delinquent, neglected, or dependent statutes. Thus in a New York survey of twelve counties only eleven per cent of adoptions were in children's courts. OsterTag REPORT 29. This means that if an action for abandonment is brought directly under the existing provisions of adoption statutes in most cases it would be heard in a higher court. In order to obtain the benefits of social courts abandonment must be sought under juvenile court statutes rather than adoption statutes where there is a choice. The solution advocated by the 
and developed flexibility administering progressive juvenile statutes. They already work closely with welfare agencies on other problems. ${ }^{35}$ Moreover, juvenile courts' special interest in preserving the family group promotes a desirable balance by protecting the natural parents.

Remedial legislation embodying an enlightened policy toward abandonment should supplement independent progress of the courts. There is a substantial gap in statutory coverage. Even the most progressive adoption statutes are concerned chiefly with child placement in adoptive homes. They fail to deal adequately with the rupture of the natural parental relationship. ${ }^{36}$ But courts need not await legislation, nor even agency development, to reform abandonment proceedings which sever parent-child bonds. Abandonment criteria are judicial, not statutory; new precedents are all that is required. Investigation, regard for the rights of both parent and child, and efforts by the court to further the social aims of adoption should ensure the child's freedom from undesirable parental ties.

social worker is to move all of child welfare litigation, including adoption, into the social courts best suited to administer it. Essentiass of Adoption LAw AND Procedure 3, 11 (Children's Bureau Publication No. 331, 1949).

The term "social court" refers to a court authorized and equipped to provide social investigation. PeCK, Adoption Laws in the United States 6 (Children's Bureau Publication No. 148, 1925).

35. See, The Court and the Children's Agency, Symposium, 28 CमIID WeLFARE 3 (July 1949).

36. Abandonment is mentioned in the adoption statutes of only twenty-six jurisdictions. 4 Vernier, AMrerican FaMIIY LaW 341 (1936). Some states make no provision whatsoever for termination of parental rights before a final decree of adoption, e.g., Missouri, communication, Mo. Dept. of Welfare, supra note 11. In other states abandonment is only a criminal action, e.g., Minnesota, communication, Minn. Dept. of Welfare, supra note 19. Nowhere are the benefits of a full agency investigation and report extended to the termination of parental rights as they are to the adoption placement. Revision of existing statutes is in order also; compare the time prescription of Texas [two years Vernon's Annotated Texas Civil Statutes ARt. 46a, 6 (cum. supp. 1950)], with that of Alaska [one month, Alaska Comp. Laws ANw. \$21-3-13 (1949)]. 